Georgetown University Law Center

Scholarship @ GEORGETOWN LAW

2015

\title{
Two Excursions into Current U.S. Supreme Court Opinion-Writing
}

Paul F. Rothstein

Georgetown University Law Center, rothstei@law.georgetown.edu

https://casetext.com/posts/two-excursions-into-current-us-supreme-court-opinion-writing

This paper can be downloaded free of charge from:

https://scholarship.law.georgetown.edu/facpub/1493

http://ssrn.com/abstract=2627777

This open-access article is brought to you by the Georgetown Law Library. Posted with permission of the author. Follow this and additional works at: https://scholarship.law.georgetown.edu/facpub

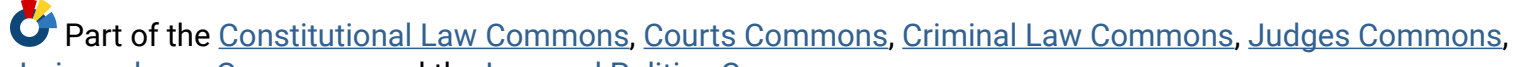
Jurisprudence Commons, and the Law and Politics Commons 


\title{
Two Excursions into Current U.S. Supreme Court Opinion-Writing
}

\author{
By: Paul Rothstein, Professor at Georgetown University Law Center
}

In the last weeks in June, 2015, as the present term of the U.S. Supreme Court drew to a close, many controversial and important decisions were handed down by the Court. The substance of the decisions has been written about extensively. Two of the decisions in particular, though, caught my eye as a teacher of legal techniques, not for the importance of the subject of the particular decision, but for what they may illustrate in a teachable fashion about at least some opinion writing. The two cases are Ohio v. Clark (June 18, 2015) interpreting the Confrontation Clause of the U.S. Constitution, and King v. Burwell (June 25, 2015) interpreting a critical provision of the Affordable Care Act (known as Obamacare, establishing national health care insurance in the U.S.). In my "excursions" into these opinions here, I am not directly concerned with the merits or desirability of the decisions.

\section{Story-Telling: the Ohio v. Clark Decision}

As lawyers well know, how you tell a story can have dramatic legal results. Clark contains an interesting example of narrative manipulation.

The question in Clark was whether a 3-year-old child's out of court statement to his pre-school teacher that defendant (his mother's boyfriend) physically abused him, could be used consistently with the Confrontation Clause when the child was incompetent to testify and didn't testify in court. The case has to do with whether the primary purpose of the statement was to get/provide evidence against the defendant, in which event it would be testimonial and inadmissible. The argument that it had that purpose hinged on the fact the teacher had a legal duty to report child abuse. Subsidiary questions had to do with whether the teacher was thus like law enforcement and police.

Here's the opening line in Justice Alito's opinion for the majority on the Court, which opinion decided the case against the defendant (as you immediately realize it is going to do when you read this opening line):

Darius Clark (the defendant) sent his girlfriend hundreds of miles away to engage in prostitution and agreed to care for her two young children while she was out of town. A day later, teachers discovered red marks on her 3-year-old son, and the boy identified Clark as his abuser.

Here's how the defendant's brief put the same technically irrelevant but emotionally persuasive fact (that the mother was involved in prostitution):

Taheim [the mother] was with L.P [the child] the rest of the afternoon and evening until she put him to sleep. At around midnight, she [the mother] caught a Greyhound bus to Washington, D.C. to engage in prostitution. Because Taheim knew that her [own] mother and aunt disapproved of what she was doing, she left 
L.P. and A.T. [the child and his sister] at her house under Clark's [the defendant's] care. The children knew Clark well and neither Taheim nor anyone else had ever seen him do anything violent.

You will note that the circumstance that the mother took a trip for prostitution is irrelevant and has nothing to do with the technical analysis involved in deciding the case, yet that information was included by both sides of the case. But each side had a way of telling exactly the same circumstance in a way that pre-disposes the reader or listener in their favor.

Comparing the two quotes above makes that evident. The first quote makes defendant look like a bad character. The second quote, combined with some other stuff about the mother, was part of a plan to make it more likely the mother was the one who beat the child-- which was indeed a realistic possibility because there was evidence she had beat him and her children before. The Supreme Court doesn't mention any of this nor even hint at any notion that the mother may have done the beating that defendant was charged with. Nor does the Court note just how shaky, uncertain, hesitant, reluctant, and unclear the child's statement identifying the defendant was, nor how he had to be pressed to make the identification. Nor did the Court mention that the child may have been aware that another sibling had been removed by social services from the mother's custody and that the present child may have wished not to be similarly removed, influencing the child to I.D. the defendant rather than the mother. It is even possible the child may have been coached by the mother regarding what to say if questioned about the injuries.

When one starts reading the Alito opinion, and sees the opening line of the opinion (i.e., the first quotation reproduced above), one says to oneself, "Why on earth would Justice Alito set forth this essentially irrelevant information?" More especially, "Why would he do it in the very first sentence of the opinion?"

There is a ready answer. It is immediately apparent from that opening line that Alito is going to decide against the defendant. He probably wanted to justify the result on an emotional as well as legal level.

Justice Alito in that opening line seems to want to evoke in the reader the cultural "Male Pimp" stereotype (putting the defendant at a disadvantage); whereas the defendant, in the excerpt from his brief reproduced above (the second quotation reproduced above), may want to evoke the "Female Prostitute" cultural stereotype (which suggests maybe the mother/"prostitute" beat the kid rather than the defendant). Thus Alito's opening line makes it look like the defendant sent his "girlfriend" to commit prostitution, whereas the way the defendant's brief puts the same information makes it look like the prostitution was all her idea.

I conclude that Justice Alito (and/or perhaps those other justices for whom he was writing) may have believed it necessary to open the opinion this way because he was (they were) a bit sensitive about the inadequacy of the decision/opinion itself. Perhaps he (they) feared that the reader (and maybe even Alito and his fellow justices themselves) would feel queasy about the opinion's result, i.e. about putting the defendant in jail for a substantial portion of his life based on such slim shaky equivocal evidence as this three-year-old's practically unintelligible, nearly coerced, totally unclear, unconfronted, unexamined statement, where the child's demeanor was not displayed to the jury-especially since it seems the mother may well have been the real 
culprit and the child may have been coached and/or influenced by fear of being removed from her.

To the extent Alito can make us (and perhaps himself and his fellow justices) see the defendant as a pimp, we (and they) don't feel so bad about putting the defendant away.

\section{A Single Word (and Politics?) May Make a Difference: The King v. Burwell Decision (Obamacare)}

How is it that the U.S. Supreme Court-including normally conservative Chief Justice John Roberts-upheld the Affordable Care Act (Obamacare)? Seems counterintuitive. The politics seems against it: A majority of the Court are conservative Republicans. The law seems against it: The critical provision of the act seems clearly to disallow certain subsidies crucial to Obamacare.

But, in politics and law, nothing is quite as it seems. Both politics and law in fact militated in favor of upholding Obamacare.

\section{The Opinion in King v. Burwell Made Sense Politically}

Quite counter-intuitively, Republicans would have been in a bind had Obamacare been struck down. They would have been deprived of a "cause” ("Repeal Obamacare!”) which they hope will be a rallying cry to help them win the next election. And they would have had to explain depriving millions of people of health care and depriving the public of some very popular provisions, such as portability and the pre-existing conditions ban. The onus would have been on Republicans to come up with a plan of their own.

Further, Chief Justice Roberts has been openly concerned that the Court was getting a political image after Bush v. Gore (in the year 2000) which gave the presidential election to George W. Bush. Is Roberts in the process of trying to correct the impression that the Court is getting polarized along political lines? He voted for Obamacare earlier as well, and has surprised us with a few other recent judicial votes leaning more liberal.

In Burwell was Roberts setting us up for an imminent opinion by him going the other way (politically speaking)? Was he engaged in some kind of advance attempt to balance the books? A Supreme Court decision according a nationwide right of same sexes to marry did come down very shortly after Burwell and Roberts did indeed file a dissenting opinion.

Or maybe in Burwell (the Obamacare decision) Roberts and Kennedy (the two deciding votes that had been in doubt) were merely concerned about being on the wrong side of history. Did they have a conscience about depriving millions of people of health care? When the law can be read either way (as usually is so when something reaches the Supreme Court) this kind of thing often influences the decision.

In each of the two decisions Justice Roberts has written for the Court upholding the Obamacare plan - a plan conservatives excoriate- he does so in a way that throws a very significant bone to conservatives - a bone that is likely to be more important to them in the long run than the 
particular ruling. In each opinion he upholds Obamacare by resort to a doctrine more limiting of governmental power than the straightforward doctrine liberals had advocated for upholding it.

Thus, in the earlier of the two decisions, he sustained Obamacare's mandate to individuals to buy insurance, by resorting to Congress's constitutional power to tax, rather than Congress's constitutional power to regulate interstate commerce, the broader power more favored by liberals. In the present case, Burwell, he sustains Obamacare subsidies by close statutory interpretation rather than by deference to the administering agency's interpretation as many liberals had urged. In each decision he rejects the more government-empowering doctrine in language that severely restricts its applicability for the future.

It should also be noted that upholding Obamacare, as the Court and Roberts did, promotes a more conservative model of according nationwide social benefits than liberals usually press for. Obamacare, by utilizing private insurance companies in the financing of health care, accords social benefits through a privatized, rather than wholly governmental, mechanism. This privatized model is likely to be preferred by conservatives regarding, for example, inevitable future reforms of social security, among other things.

\section{The Opinion in King v. Burwell Made Sense Legally}

Writing for the majority, Justice Roberts holds in Burwell that the single, small word "such" (that appears in the Act) substantially rescues Obamacare. This again is quite counter-intuitive. But it makes sense. It was critical to parsing the legal text and instrumental in the result.

The question in the case was whether there could be subsidies to the millions of poor people who bought their health insurance on federal exchanges that were established by the federal government for those very numerous states that refused (for political or other reasons) to set up their own exchanges. The letter of the law provided only for subsidies if insurance was bought on state-established exchanges.

But if subsidies were so limited, Obamacare would probably financially implode. Roberts saves the day for Obamacare by holding that the phrase "such exchanges" (appearing in the Act arguably in connection with the subsidies) made it ambiguous what exchanges could carry the subsidies. In other words, when the federal government set up exchanges for states, those exchanges might be included as state exchanges.

If a law is ambiguous, Roberts is then entitled to invoke, as he did, the well known axiom of statutory construction that the overall purpose of Congress in enacting the scheme under consideration should prevail. Here, that purpose was to have a viable national healthcare plan. Without the subsidies in those states that did not set up their own exchanges, the future of Obamacare's overall mission would be gravely in doubt.

\section{Who is the Dreaded "Judicial Activist"?}

A final conundrum in Burwell is worth noting.

An oft-repeated rubric in the United States is that Congress, consisting of the people's representatives, writes the laws, whereas judges (who are usually unelected) merely apply them. 
There is an ongoing battle over when the courts may be regarded as transgressing that line between the institutions. When people feel a judge has overstepped, they call the judge a "judicial activist." But in reality, the line is often blurry and the charge of judicial activism tends to be made by individuals against any judge whose opinions the individual doesn't like.

In his dissent in Burwell Justice Scalia accuses the majority in the case (including Chief Justice Roberts) of judicial activism — of re-writing the law to uphold Obamacare. Scalia scathingly concludes that Obamacare should now be called "SCOTUScare" ("SCOTUS" being a wellknown acronym for "the Supreme Court of the U.S.") because the Supreme Court (and Roberts) have twice re-characterized provisions to foster the health care scheme.

Chief Justice Roberts, on the other hand, sees Justice Scalia's dissent as the activist view: Roberts declares that he (Roberts) does not want to be a judicial activist by overturning Congress's intention in enacting Obamacare. He accuses Scalia of voting to do just that.

\section{Conclusion}

Perhaps one overall message from the two current cases treated in this piece, aside from their merits, is that there is always more going on than meets the eye. And I have only scratched the surface. 